\title{
A COMPARATIVE STUDY OF O. HENRY AND PANNALAL PATEL'S SELECTED LOVE STORIES
}

\author{
Dr. Shaurya Brahmbhatt \\ Ms. Jayana Jayendrabhai Gajjar
}

\begin{abstract}
:
'Love' has always been a topic of interest for people around the world. Poets, novelists, painters, dancers have multiple works dedicated to 'love' and it seems they can't get enough of it. Friendship, anger, cares, jealousies are emotions attached to love and have been dealt with by authors of the world. The ancient and the modern, the teens and the adults, males and female are in awe of 'love'. This makes it a very interesting subject for study. William Sydney Porter, better known as O. Henry has written almost 300 short stories on various themes. He never failed to surprise the readers with a twist at the end of his stories. Pannalal Patel is a celebrated Gujarati author who, like Henry, has almost 20 short story collection under his name. He too has dealt with various themes including love, crime, sacrifice and more. The current paper focuses on comparing the love stories by these authors. The selected stories are The Gift of Magi and Witches' Loaves by O. Henry and Sukh Dukh na Sathi and Nirupay by Pannalal Patel. As both, the writers belonged to two entirely different places and were active during a different time, the comparison of their stories will help to learn the idea of 'love' as the authors see it and the treatment of 'love' in their stories.
\end{abstract}

Key Words: jealousy, ancient, celebrated, entirely, treatment

"Do not pity the dead, Harry. Pity the living, and, above all those who live without love." Says professor Dumbledore reminding Harry of the importance of love in one's life. Stands true. Isn't it? Love sometimes takes the disguise of care, friendship, jealousy, or anger even. Parents work hard to give their children a better life and comfort because they love them, love can make you jealous as you see your partner talking to someone else, it gets converted into taking care of the partner once time passes and in the end, all matters is just being 
together and having someone by your side when you need it. All may agree that it is ultimately this inexplicable feeling called 'love' and its variants that keep us going.

O. Henry's skills of mixing love with a twist were exceptionally well. Among the plethora of his mind-blowing works, a considerable part is dedicated to love. It was taken as the central idea for many of his stories.

The current paper focuses on making a comparative study of the selected short stories of the noteworthy American writer William Sydney Porter (1862-1910), famously known by his pseudonym O. Henry and equally talented Gujarati writer Pannalal Patel (1912-1989). Although they belong to an entirely different age, culture, and region they have some similarities in the themes of their stories, characters, and techniques.

O. Henry, a name without the mention of which any discussion on a short story is incomplete, is one of the major contributors of the genre. His unique way of ending each story with a twist made him immensely popular among the readers. His literary prowess is seen in his knowledge of holding his reader's interest and leaving them and curious till the end of the story. His works are the reflection of people and society around him. He wrote in the language that people spoke. He took a risk by throwing away the idea of portraying the aristocrats in his stories and write about middle-class folks. This perhaps was one of the reasons that he could connect to the people of all classes thereby becoming the most celebrated short-story writer. He never took his mind off his people and his surroundings. His popularity lies in his lucid language, straightforward characters, and perfect twist at the end of the stories.

One cannot help but notice his successful attempts at dealing with a wide range of themes. In his, The Ransom of Red Chief he is showing the act of kidnapping in a humorous light, with The Guilty Party and Memento Henry tries to shift focus from stereotypical stories with a male protagonist to female-centric stories. He has given us The Gift of the Magi, a classic example of love and sacrifice, and The Trimmed Lamp that simply shows different mindsets and perspectives that people have regarding lives.

Pannalal Patel, the second Gujarati writer to receive the prestigious Jnanpith Award, is one of the literary geniuses that the people of Gujarat are tremendously proud of having. He began writing in 1936 and enriched Gujarati literature till his death. While dealing with different themes, he also tried his hands on various forms such as the novel, short stories, one-act 
plays, and children's literature not failing to amaze and entertain his readers. He was quite similar to O. Henry when it comes to picking up the themes or picking the characters. Like Henry, Patel too was taking his inspiration from his surroundings. His characters were the people who the readers saw around them and could relate to easily. The readers understood their problems and feelings. His idea of portraying the middle-class folks and the simplicity of the language brought him fame along with the plenitude of the love of the people.

His more than 20 short story collections, novels, and other works are the flawless portrayal of people, their hopes, ambitions, triumph, and their emotions.

\section{The Gift of the Magi and Sukh Dukh na Sathi}

"The greatest sacrifice is when you sacrifice your happiness for someone else", they saymostly holds for the emotion we know as 'love'. One is ready to give away everything he/she has as the other person's happiness becomes important. What can be a better example of love and sacrifice than Henry's The Gift of Magi'. A story of pure love and sacrifice, written so well that touched the hearts of thousands. Jim and Della, a couple who probably did not have much money, but had a love for each other by their sides. Della's long, brown, cascade-like hair is the only priced possession she has. Jim too had a gold watch that belonged to his very precious father. For Christmas, Della sells off her beautiful hair to buy a watch chain for Jim's watch. Jim had bought a nice comb for Della's beautiful, long hair only to realize that the hair was chopped off. Both the husband and wife give away their prized possession to make the other happy. Their possessions were gone, but they're still were love.

Patel's Sukh Dukh na Sathi portrays that nothing matters when it comes to love. It is a tale of blind Jamni spends her life begging as she cannot do anything else. She meets Chaman, knowns as Chamno who doesn't have a leg. Gradually, they start begging together. Each feels that the other is his/her responsibility and takes care of each other. Chamno takes Jamni to a little place where he lives and both start living together. They seem happy in their way. When Chamno falls seriously ill, Jamni had to go begging as she needed money. On her return, she sees municipal people taking away Chamna's dead body. All efforts she had put in to get some money were now in vain as the person she loved was gone forever.

Both the stories show that nothing stands between the two people who understand pure love. For Jim and Della, their poverty did not matter against their love and their deformity did not come in between their love for Jamni and Chamno. Accepting the partners as they are and 
cherishing togetherness is what these characters knew. These stories make people believe that in this rapidly changing world where there is hardly a place for any emotion, true love does exist.

\section{Witches' Loaves and Nirupay:}

Fortunate are those who get the love for life but not everyone is blessed with such fortune, not every love story has a perfect end, not everyone's love is reciprocated.

Henry's 'Witches' Loaves' is a story of unrequited love. Miss Martha, a lady in her forties, runs a bakery. As the author says, "Her bank-book showed a credit of two-thousand dollars, possessed two false teeth and a sympathetic heart." She finds herself taking interest in one of her customers who was a middle-aged man with a heavy German accent. He used to buy two loaves of stale bread from her. Her little affection led her to help him a little and she put a generous amount of fresh butter between the loaves. Little did she know that her efforts of showing her love by adding butter in the loaves had made the customer livid. It was later revealed that her customer, Mr. Blumberger was drawing the plan for the city hall for a competition. He was using the breadcrumbs to rub out the pencil lines. Her butter had ruined his drawing. Both could see their dreams shattering. The artist of winning the competition and Miss Martha of being with him and getting his love.

Patel's Nirupay' is a story of Leela and Vinod who were madly in love with each other and were dreaming of having a married life full of love. Leela was broken when she learned about Vinod's marriage with Manorama and so was Vinod himself. Both write in letters to each other that they will try to forget their love. They meet after two years in a marriage. The past lovers act strangely with each other trying hard to conceal their love. Vinod ultimately takes her to leave as he knew he was nirupay meaning he did not have any option but to go back to his wife and children.

Henry's Martha is a character whose love was not reciprocated and Patel's characters, even being in love, could not be together. One important key of any successful relationship is proper communication which was lacking in both the stories. Martha never expressed her feelings verbally and the way she chose to show her affection turned out to be a complete failure. Vinod never explained his reasons for not marrying Leela. This doesn't put his love in question but had these characters talked before to each other, the result probably would 
have been different. Martha too never intended to spoil her customer's drawing, but the wrong mode of communication proved to be destroying everything.

'Nirupay' depicts a mature love story and 'Witches' Loaves' displays not-so-deep love, but the characters do go through similar emotions. Martha probably did not think of living a life together with her German customer but she did expect the same interest from him which will allow them to spend some time together. All Leela and Vinod wanted were to spend the rest of their lives together. But that did not happen for any of them.

To conclude, we see that both Henry and Patel have dealt with the theme of love and sacrifice in their different ways. Henry's 'The Gift of Magi' stands as a very beautiful example of pure and unconditional love where money doesn't matter. Patel's 'Sukh Dukh na Sathi' shows a variant of love i.e. care. Jamni and Chamno translate their love for each other into care. How the lack of proper communication can break hearts is depicted in 'Nirupay' and Miss Martha's little help to show her affection to Mr. Blumberger ruins the latter's drawing for a prize competition.

The authors have many love stories under their names, each putting 'love' in a different light. In a world full of broken and empty hearts, these love stories soothe and comfort the heart that all's well with the world. 
Towards Excellence: An Indexed, Refereed \& Peer Reviewed Journal of Higher Education /

Dr. Shauyrya Brahmbhatt \& Ms. Jayana Gajiar / Page 461-467

\section{Work Cited}

Henry, O. (1995). 100 Selected Stories.United Kingdom: Wordsworth Classics.

---.(2015). O. Henry Collected Stories: Projapoti.

---.(2009). The O. Henry Short Story Collection. United States: Rough Draft Printing.

--- (2017). O. Henry, Best Short Stories. (n.p.): CreateSpace Independent Publishing Platform.

--- Henry, O., Nemo, A. (2020). 7 Best Short Stories by O. Henry. Germany: Tacet Books.

Patel, Pannalal. (2008). Vineli navlikao. India: Sanjivani Prakashan.

---. (2012). Aasmani Najar. Ahmedabad: Sanjeevni.

---. (2015). Sacha Samna. Ahmedabad: Sanjeevni, 2015.

Secondary Sources:

C. Alfonso Smith. O. Henry: A Biography. Garden City, NY: Doubleday Page. 1916. 258pp.

Dave, R.R. and Desai, P. K. Ed. Gujarati Sahityano Itihas: Vol. 6. Ahmedabad: Sahitya Parisad.

2006. Print.

Hansen, A. J. (2015). Short story: Additional Information. Retrieved December 10, 2020, from http://www.britannica.com/art/short-story/additional-info

Hudson, W. H. (2015). An Introduction to the Study of Literature. India: Rupa.

Pannalal Patel. (2020, December 09). Retrieved December 10, 2020, from https://en.wikipedia.org/wiki/Pannalal_Patel

Rees, R. J. (1973). English Literature:An Introduction for Foreign Readers. United Kingdom: Macmillan.

Reid, Ian. (2017). The Short Story. United Kingdom: Taylor \& Francis.

Richard O'Connor. (1970). O. Henry: The Legendary Life of William S. Porter. Garden City. NY: Doubleday \& Co.. 252pp.

\section{Dr. Shaurya Brahmbhatt Assistant Professor, Department of English, Faculty of Arts}


Towards Excellence: An Indexed, Refereed \& Peer Reviewed Journal of Higher Education / Dr. Shauyrya Brahmbhatt \& Ms. Jayana Gajjar / Page 461-467

The Maharaja Sayajirao University of Baroda, Vadodara

E-Mail: Shaurya.b-eng@msubaroda.ac.in

\&

Jayana Jayendrabhai Gajjar

Ph.D Research Scholar,

Department of English, Faculty of Arts

The Maharaja Sayajirao University of Baroda, Vadodara.

E-Mail: khushigajjar004@gmail.com 